\title{
The International Life of a Russian Colonial Document: The Russian-American Company, the Kashaya Pomos, the Bodega Miwoks, and the 1817 Métini Protocol
}

Jeffrey Glover

Loyola University Chicago, jglover@luc.edu

Follow this and additional works at: https://ecommons.luc.edu/english_facpubs

Part of the English Language and Literature Commons

\section{Recommended Citation}

Glover, Jeffrey. The International Life of a Russian Colonial Document: The Russian-American Company, the Kashaya Pomos, the Bodega Miwoks, and the 1817 Métini Protocol. Early American Studies: An Interdisciplinary Journal, 18, 2: 139-172, 2020. Retrieved from Loyola eCommons, English: Faculty Publications and Other Works, http://dx.doi.org/10.1353/eam.2020.0006

This Article is brought to you for free and open access by the Faculty Publications and Other Works by Department at Loyola eCommons. It has been accepted for inclusion in English: Faculty Publications and Other Works by an authorized administrator of Loyola eCommons. For more information, please contact ecommons@luc.edu. (c) University of Pennsylvania Press, 2020.

All rights reserved. Except for brief quotations used for purposes of scholarly citation, none of this work may be reproduced in any form by any means without written permission from the publisher. For information address the University of Pennsylvania Press, 3905 Spruce Street, Philadelphia, Pennsylvania 19104-4112. 


\title{
The International Life of a Russian Colonial Document
}

\author{
The Russian-American Company, the Kashaya Pomos, the \\ Bodega Miwoks, and the 1817 Métini Protocol
}

\author{
JEFFREY GLOVER \\ Loyola University Chicago
}

\begin{abstract}
In September 1817 officials of the Russian colony of Ross drafted a protocol of a meeting held with the Kashaya Pomos, the Bodega Miwoks, and other Native Americans. The protocol described how the Russians had promised gifts and military protection to their Native American allies in exchange for the right to continue occupying Métini, a Kashaya Pomo-controlled territory about eighty-five miles north of San Francisco. Soon, reports of the meeting had made their way up and down the coast and across the Pacific, as Native Americans, Russian imperial ministers, and diplomats from Russia's imperial rivals debated its significance. This essay describes how the Russian-American Company used the protocol and other agreements with Native Americans to lay claim to coastal territories, and how Russia's imperial rivals disputed such claims. It argues that company officials used documentation of Native American signs of consent, such as speeches and gestures, to assert ownership of Métini, while Spain disputed the validity of agreements with Native Americans. The meaning that Russian officials assigned to Native Americans' consent enabled the Kashaya Pomos, the Bodega Miwoks, and other groups to exert some influence over Russian colonization and trade.
\end{abstract}

The author would like to dedicate this article to Anastasia S. Kondrasheva, who did so much to bring together different parts of the world. He would also like to thank Glenn Farris, Ilya Vinkovetsky, James Gibson, Sergei Kan, Michael Khodarkovsky, Kent G. Lightfoot, Irina Lukka, Polina Pak, and Simeon Tsinman for help with matters large and small. Finally, he would like to thank Kelsey Rydland of Research and Learning Services at Northwestern University Libraries for exceptional assistance with the map, as well as the anonymous reviewers for their immensely helpful critiques. This essay uses the United States Board on Geographic Names system for transliterating Russian, except in the case of names already wellknown in English under other transliterations.

Early American Studies (Spring 2020)

Copyright (C) 2020 The McNeil Center for Early American Studies. All rights reserved. 
On September 22, 1817, Kashaya Pomo leaders Chu-gu-an and Amat-tan and Bodega Miwok leader Gem-le-le arrived at Ross, a Russian colony built on land known as Métini to its Kashaya Pomo residents. ${ }^{1}$ There to welcome them was Captain Lieutenant Leontiy Hagemeister, a Russian-American Company official who sought their blessing for the Russian presence. But Hagemeister also had an ulterior motive: he planned to exploit the tribes to prove Russian land rights to Spain, which had an outpost eighty-five miles south at San Francisco. After the meeting was over, company officials drew up a protocol - or diplomatic minutes - of the day's proceedings. The document described Chu-gu-an making an act of "cession" or legal transfer of land to the company. It also said he accepted "gifts" and "refreshments" (including a medal inscribed "Allies of Russia") and joined a defense pact with the Russians "against other Indians." ${ }^{2}$ The Russians had ostensibly made a perfectly legitimate deal with tribal leaders-land for military aid.

1. The Bodega Miwoks were part of the Coast Miwoks and lived at Bodega Bay. Amat-tan may have been Southern Pomo, a Pomo-speaking group that occupied territory primarily to the north and west of Kashaya Pomo lands. See Robert Oswalt to Alexei A. Istomin, 8 June 1981, personal correspondence, cited in James R. Gibson and Alexei A. Istomin, comps. and eds., Russian California, 1806-1860: A History in Documents, trans. James R. Gibson (London: Hakluyt Society, 2014), vol. 1, $322 \mathrm{n} 2$. However, the protocol's description of his residence as "not distant" suggests an affiliation with the Kashaya Pomos; see Russian California (hereafter cited as $R C$ ), 1:322. Today, the Kashia Band of Pomo Indians of the Stewarts Point Rancheria and the Federated Indians of Graton Rancheria are federally recognized tribes. This essay will use tribe to describe them. The date of the meeting is given in the Julian calendar.

2. $R C, 1: 322$. An English translation of the treaty appears in $R C, 1: 322-23$. For a Russian transcription, see "Protokol vstrechi v Rosse indeyskikh vozhdey s kapitan-leytenantom L.A. Gagemeysterom, udostoveryayushchiy ikh druzheskie otnosheniya s russkimi," in A. A. Istomin, Dzh. R. Gibson, and V. A. Tishkov, comps. and eds., Rossiya v Kalifornii: russkiye dokumenty o kolonii Ross $i$ rossiyskokaliforniyskikh svyazyakh 1803-1850 (Moscow: Nauka, 2005), 1:257-59. The sole surviving manuscript of the treaty is located in the Arkhiv vneshney politiki Rossiyskoy Imperii (Archive of the Foreign Policy of the Russian Empire), Moscow. Transcriptions of parts of the document and a discussion appear in N. N. Bolkhovitinov, Russko-Amerikanskiye otnosheniya: 1815-1832 (Moscow: Nauka, 1975), 142. For the history of the treaty and the first English translation, see Diane SpencerHancock and William E. Pritchard, "Notes to the 1817 Treaty between the Russian-American Company and Kashaya Pomo Indians," trans. Ina Kaliakin, California History 59, no. 4 (1980/1981): 306-13. Another translation appears in Basil Dmytryshyn, E. A. P. Crownhart-Vaughan, and Thomas Vaughan, eds., The Russian American Colonies, 1798-1867: A Documentary Record (Portland: Oregon Historical Society Press, 1989), 296-98. 
Hagemeister duly sent the protocol to St. Petersburg, hoping the czar's ministers would show it to Spain. ${ }^{3}$

Yet for all its proper legal form, the protocol did not seem to convince anyone of Russian rights. A Russian sailor on the ship back to St. Petersburg scoffed at its contents, claiming that tribal leaders could not have understood what it meant. ${ }^{4}$ Russian imperial ministers took an equally skeptical view, asking company officials to account for the medals they handed out. ${ }^{5}$ Some Bodega Miwoks also demurred, telling a Spanish padre that the Russian-American Company had negotiated only modest rights to Métini. ${ }^{6}$ And most ominous were the actions of Spanish officials in San Francisco, who had a plan in motion to destroy the colony and showed no sign of acknowledging Russian claims. ${ }^{7}$ Though meant to prove its claim to Métini once and for all, the protocol left the company only more uncertain of its rights.

The 1817 Métini protocol shows the importance of Native Americans in imperial conflicts over Pacific land rights. Documentation of diplomacy with Native Americans was central to the Russian-American Company's colonial endeavors in California. Lacking the might for violent conquest, the company instead tried to get land by making agreements with Native Americans. This legal strategy was well established in international law.

3. For the protocol's path to St. Petersburg, see $R C$, 1:390. Hagemeister also took a copy of the protocol to company headquarters in New Archangel (modernday Sitka, Alaska), where it made its way to St. Petersburg on the Suvorov, which returned to Russia on October 18, 1818. The existence of such correspondence is indicated by a reference to the treaty in a report of the company's board to Alexander I that postdates the return of the Suvorov but predates Hagemeister's return on the Kutozov and Golovnin's return on the Kamchatka. See "Glavnoye pravleniye Rossiysko-Amerikanskoy kompanii Aleksandru I,” in Aleksey Narochnitskiy, ed., Vneshnyaya politika Rossii XIX $i$ nachala XX veka: Dokumenty Rossiyskogo Ministerstva Inostrannykh Del, series 2 (Moscow: Politicheskaya Literatura, 1976), 10:576. See also the report by Hagemeister quoted in Alexey Postnikov and Marvin Falk, Exploring and Mapping Alaska: The Russian-American Era, 1741-1867, trans. Lydia Black (Fairbanks: University of Alaska Press, 2015), 278.

4. $R C, 1: 390$.

5. $R C, 1: 404$.

6. Mariano Payeras, Writings of Mariano Payeras, trans. and ed. Donald C. Cutter (Santa Barbara, Calif.: Bellerophon Books), 335.

7. For the interrogation, see $R C, 1: 399$; and Otto Von Kotzebue, $A$ New Voyage Round the World, in the Years 1823, 24, 25, and 26 (London, 1830), 2:122. For the plan to destroy the colony, see W. Michael Mathes et al., The Russian-Mexican Frontier: Mexican Documents Regarding the Russian Establishments in California, 1808-1842 (Jenner, Calif.: Fort Ross Interpretive Association, 2008), 108. 
Western powers often brandished contracts and treaties with Native Americans to claim colonial territory. ${ }^{8}$ Yet in the case of the Russian-American Company's bid for Métini-a territory claimed by multiple imperial powers - this strategy did not succeed. The protocol persuaded few and was summarily rejected by the Russian government and Russia's imperial rivals. Given its failure, the protocol could be dismissed as a botched effort to defend a doomed colony that would be sold off in 1841. Still, the story of its creation and circulation reveals a much broader picture of how different imperial powers used Native Americans to justify colonial claims. It also shows how Native Americans used their relationships with imperial diplomats to negotiate trade deals and military alliances. As the controversy over the Métini protocol reveals, documents of interactions with Native Americans took on importance far from colonial contact zones and shaped imperial contests for land along the Pacific coast.

Existing scholarship on the Métini protocol emphasizes its importance to the Russian-American Company's relationship with the imperial government. ${ }^{9}$ Ross had a precarious place in the Russian Empire. Company officials built the colony without the czar's explicit permission, settling on a contested territory between the Spanish presidio at San Francisco and an American outpost at the Columbia River. They sent home documents such as the protocol hoping that Russian diplomats would defend their land claims to foreign rivals. Such documents were part of a complex international lobbying effort meant to persuade their own government as well as

8. Since the Russians and their European rivals in California used varied elements of imperial law, natural rights, and the law of nations to stake claims in North America, this essay will use the generic term international law to describe the rules and norms European states cited in their dealings with one another. For accounts of Europeans using contracts with Native Americans to claim land in North America, see Stuart Banner, How the Indians Lost Their Land: Law and Power on the Frontier (Cambridge: Belknap Press of Harvard University Press, 2005); Francis Paul Prucha, American Indian Treaties: The History of a Political Anomaly (Berkeley: University of California Press, 1994); and Colin G. Calloway, Pen and Ink Witchcraft: Treaties and Treaty Making in American Indian History (New York: Oxford University Press, 2013). For a global view, see Jennifer Pitts, Boundaries of the International: Law and Empire (Cambridge : Harvard University Press, 2018).

9. Accounts of the treaty emphasizing its imperial context can be found in P. A. Tikhmenev, A History of the Russian-American Company, trans. and ed. Richard A. Pierce and Alton S. Donnelly (Seattle: University of Washington Press, 1978) [originally published 1861-63], 139-40; Bolkhovitinov, Russko-Amerikanskiye otnosheniya, 140-44; and Spencer-Hancock and Pritchard, "Notes to the 1817 Treaty," 306-13. 
foreign opponents of their rights to colonial territory. However, although the importance of the protocol to the company's lobbying has been well established, the role of Native Americans in its diplomatic strategy deserves greater attention.

The Métini protocol documented the Russian-American Company's relationship with Native Americans-specifically the Kashaya Pomos, who occupied the land where Ross was built; and the Bodega Miwoks, part of the Coast Miwoks, who lived about twenty miles south, and on whose territory the company built Port Rumyantsev in 1809. The 1817 exchange was part of a longer history of interactions with Native Americans that dated to the beginning of Russian arrival in the Americas in 1741. Before the protocol, Russians had made contact with Native Americans in Alaska, Hawaii, California, and other areas visited or colonized by Russian-led ventures. ${ }^{10}$ Many of these interactions were violent. In Alaska, for example, Russians brutally subjugated Aleuts and Tlingits, taking them hostage and forcing them into slavery. In early California, however, Russians initially established

10. On the Russian-American Company in Alaska, see Lydia T. Black, Russians in Alaska, 1732-1867 (Fairbanks: University of Alaska Press, 2004); Andrei Val'terovich Grinev, The Tlingit Indians in Russian America, 1741-1867 (Lincoln: University of Nebraska Press, 2005); A. V. Grinëv, “Tuzemtsy Alyaski, russkiye promyshlenniki i Rossiisko-Amerikanskaya kompaniya: sistema ekonomicheskikh vzaimootnoshenii," Etnogracheskoye obozreniye 3 (2000), 74-88; "Kharakter vzaimootnosheniy russkikh kolonizatorov i aborigenov Alyaski," Voprosy istorii 8 (2003), 96-111; Andrei V. Grinëv, "The Dynamics of Barter Between the Russians and Alaskan Natives, 1741-1867," Folk Life 55, no. 2 (2017): 67-87, among other articles by the same author; A. V. Zorin, "Mezhdu dvukh ogney: indeitsy denayna i russkie mekhopromyshlenniki v kontse XVIII veka," in A. A. Borodatova and V. A. Tishkov, eds., Vlast' $v$ aborigennoy Amerike (Moscow: Nauka, 2006), 592-610, among other articles by the same author; and Sonja Luehrmann, Alutiiq Villages under Russian and U.S. Rule (Fairbanks: University of Alaska Press, 2008). For an account of the Tlingit perspective on wars with the Russians, see Nora Marks Dauenhauer, Richard Dauenhauer, and Lydia T. Black, Anóoshi Lingít Aaní Ká / Russians in Tlingit America: The Battles of Sitka, 1802 and 1804 (Seattle: University of Washington Press, 2008). For Russians in Hawaii, see Peter R. Mills, Hawai'i's Russian Adventure: A New Look at Old History (Honolulu: University of Hawaii Press, 2002); and Richard A. Pierce, Russia's Hawaiian Adventure, 1815-1817 (Berkeley: University of California Press, 1965). Yuri Slezkine, Arctic Mirrors: Russia and the Small Peoples of the North (Ithaca: Cornell University Press 1996) is a study of Russian colonization of Siberia, a precedent for later Pacific colonization. For a fuller account of the recent Russian-language historiography of Russian America, see Andrei V. Grinëv, "A Brief Survey of the Russian Historiography of Russian America of Recent Years," trans. Richard L. Bland, Pacific Historical Review 79, no. 2 (2010): 265-78. 
diplomatic contacts with Kashaya Pomo and Coast Miwok leaders, negotiating for land, labor, and military aid using gifts, goods, and imperial artifacts such as medallions and flags. ${ }^{11}$ Though they later conscripted Kashaya Pomos into forced labor, these initial contacts involved some element of

11. The major documentary sources for the study of Russian California are A. A. Istomin, Dzh. R. Gibson, and V. A. Tishkov, comps. and eds., Rossiya v Kalifornii; and in English, RC. On Russian California, see James R. Gibson and Alexei A. Istomin, "Introduction," in $R C, 1: 1-173$; and Glenn J. Farris, "The Russian Imprint on the Colonization of Califomia," in Columbian Consequences, vol. 1, Archaeological and Historical Perspectives on the Spanish Borderlands West, ed. David Hurst Thomas (Washington, D.C.: Smithsonian Institution, 1989), 481-97, among other articles by the same author. Accounts of the Russian-American Company that provide important context for understanding Russian colonization in California include James R. Gibson, Imperial Russia in Frontier America: The Changing Geography of Supply of Russian America, 1784-1867 (New York: Oxford University Press, 1976); A. Iu. Petrov, Rossiysko-Amerikanskaya Kompaniya: deyatel'nost' na otechestvennom i zarubezhnom rynkakh, 1799-1867 (Moscow: Russian Academy of Sciences, 2006); Ilya Vinkovetsky, Russian America: An Overseas Colony of a Continental Empire, 1804-1867 (New York: Oxford University Press, 2011); and Kenneth N. Owens with Alexander Yu. Petrov, Empire Maker: Aleksandr Baranov and Russian Colonial Expansion into Alaska and Northern California (Seattle: University of Washington Press, 2015). Anthologies of Russian writings about the settlement of Fort Ross include Glenn J. Farris, ed., So Far From Home: Russians in Early California (Berkeley, Calif.: Heyday, 2012); and James R. Gibson, ed., California Through Russian Eyes, 1806-1848 (Norman: University of Oklahoma Press, 2013). For Russianlanguage scholarly works from the imperial era that touch on California, see P. A. Tikhmenev, Istoricheskoye obrozreniye obrazovaniye Rossiysko-amerikanskoy kompanii $i$ deystviy eyë do nastoyashchego vremeni, two vols. (St. Petersburg, 1861-63), trans. in Tikhmenev, A History of the Russian-American Company; and V. A. Potekhin, "Selenie Ross," Zhurnal manufaktur i torgovli 8 (St. Petersburg, 1859), 1-42. For Soviet-era works on the Russian-American Company that mention Russian California, see Semën Okun, Rossiysko-Amerikanskaya Kompaniya (Moscow: State Socio-Economic Press, 1939), trans. in S. B. Okun, The Russian-American Company, ed. B. D. Grekov, trans. Carl Ginsburg (Cambridge: Harvard University Press, 1951); N. N. Bolkhovitinov, Stanovleniye Russko-Amerikanskikh otnosheniy, 1775-1815 (Moscow: Nauka, 1966), trans. in Nikolai N. Bolkhovitinov, The Beginnings of Russian-American Relations, 1775-1815, trans. Elena Levin (Cambridge: Harvard University Press, 1975); Bolkhovitinov, Russko-Amerikanskie otnosheniya; A. I. Alekseyev, Sud'ba Russkoy Ameriki (Magadan, Russia: Magadan Book Publishing House, 1975), trans. as A. I. Alekseev, The Destiny of Russian America 17411867, ed. R.A. Pierce, trans. Marina Ramsay (Kingston, Ontario: Limestone Press, 1990); and Svetlana G. Fedorova, Russkoye naseleniye Alyaski i Kalifornii. konets XVIII v. $-1867 \mathrm{~g}$ (Moscow: Nauka, 1971), trans. as Svetlana G. Fedorova, The Russian Population in Alaska and California, Late 18th Century-1867, trans. and ed. Richard A. Pierce and Alton S. Donnelly (Kingston, Ontario: Limestone Press, 
reciprocity. ${ }^{12}$ Russians offered gifts for peace; Native Americans' took Russian- and Asian-made goods to trade with other tribes and kin groups. ${ }^{13}$ By 1817 Russian-American Company officials had held many meetings with coastal leaders-including at least one where they discussed Russian rights to Métini. ${ }^{14}$

This earlier history of cross-cultural exchange between Russian-speaking colonists, Kashaya Pomos, Coast Miwoks, and other tribes is an important context for understanding the Métini protocol. The document was an attempt to frame the Russians' entire history of interactions with the Kashaya Pomo and Coast Miwok tribes as a single act of land cession that Spain, the United States, and the Russian imperial government would recognize as legally valid. As it turned out, however, the Russians could not

1973). For more recent Russian-language scholarship, see the essays in N. N. Bolkhovitinov, ed., Istoriya Russkoy Ameriki (1732-1867), three vols. (Moscow: International Relations, 1997-99). On Native American groups during the era of Russian colonization, see Kent G. Lightfoot, Native Americans, Missionaries, and Merchants: The Legacy of Colonial Encounters on the California Frontiers (Berkeley: University of California Press, 2005); Ed D. Castillo, "The Native Response to the Colonization of Alta California," in Thomas, Columbian Consequences, 1:377-94; Julia G. Costello and David Hornbeck, "Alta California: An Overview," in Thomas, Columbian Consequences, 1:303-31; George Harwood Phillips, Indians and Intruders in Central California, 1769-1849 (Norman, Okla.: University of Oklahoma Press, 1993); A. A. Istomin, "Russko-indeyskiye kontakty v svete novykh dannykh," in Amerikianskiye indeytsy: novyye fakty $i$ interpretatsii problemy indeanistiki, ed. V. A. Tishkov (Moscow: Nauka, 1996), 26-47; A. A. Istomin, “'Indeiskii faktor' v kaliforniyskoi politike Rossiysko-Amerikanskoy kompanii na nachal'nom etape kolonizatsii (1807-1821 gg.)," in A. A. Borodatova and V. A. Tishkov, eds., Istoriya i semiotika indeiskikh kul'tur Ameriki (Moscow: Nauka, 2002), 452-463; and A. A. Istomin, "Indeiskaya politika rossiyskoi kolonial'noy administratsii v Kalifornii v1821-1841 godakh" in A. A. Borodatova and V. A. Tishkov, eds., Vlast' $v$ aborigennoy Amerike (Moscow: Nauka, 2006), 500-24, among other articles by the same author. For Ross and the surrounding area, see Sally McLendon and Michael J. Lowry, "Eastern Pomo and Southeastern Pomo," in Robert F. Heizer, ed., Handbook of North American Native Americans, vol. 8: California (Washington, D.C.: Smithsonian Institution, 1978), 306-23; Sally McLendon and Robert L. Oswalt, "Pomo: Introduction," in Handbook of North American Native Americans, 8:274-88; and Beverly R. Ortiz, "A Bodega Miwok History," in Kathleen Smith, ed., We Are Still Here: A Bodega Miwok Exhibit (Bolinas, Calif.: Bolinas Museum, 1993).

12. See James R. Gibson, "Russia in California, 1833: Report of Governor Wrangel," The Pacific Northwest Quarterly 60, no. 4 (1969): 210.

13. Russians also took away many Native American artifacts. See Travis Hudson and Craig D. Bates, Treasures from Native California: The Legacy of Russian Exploration, eds. Thomas Blackburn and John R. Johnson (New York: Routledge, 2016).

14. Tikhmenev, A History of the Russian-American Company, 134. 


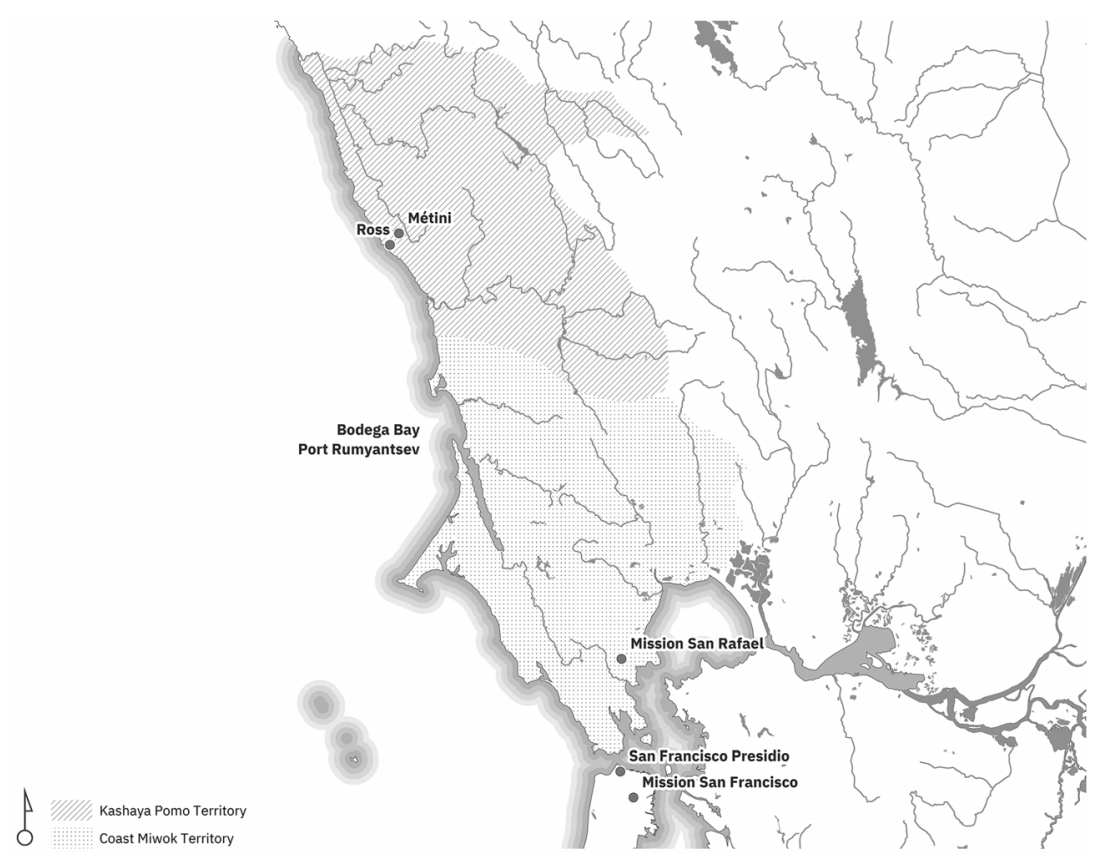

Figure 1. Kashaya Pomo and Coast Miwok California in the early years of Russian settlement. Adapted from Sally McLendon and Robert L. Oswalt, "Pomo: Introduction," figure 3, in William C. Sturtevant, ed., Handbook of North American Indians, vol. 8, California, ed. Robert F. Heizer (Washington, D.C.: Smithsonian Institution, 1978), 278; and Isabel Kelly, "Coast Miwok," figure 1, ibid., 415.

control the story of their negotiations with coastal tribes, nor could they dictate how outsiders would understand it. Many players in the regionRussian, Spanish, and Native American - would have different stories to tell about the 1817 meeting, and with them, different claims to make.

\section{COASTAL DIPLOMACY: THE RUSSIAN-AMERICAN COMPANY AND THE FOUNDING OF ROSS}

In drafting the protocol, Russian-American Company officials claimed disputed territory. Ross was located north of the Spanish settlements of Alta California, a colonial network of missions, presidios, and pueblos spread out along the coast from San Diego to the presidio at San Francisco (see figure 1). Russians called this territory "New Albion" using Sir Francis Drake's name for it. Their decision to claim it by Native American land 
cession emerged from a legal controversy between the Russian-American Company, the Russian imperial government, and Spanish ambassadors. ${ }^{15}$ The dispute pitted Spanish assertions of rights based on discovery against Russian rights based on Native American cession. The Métini protocol was a carefully crafted legal document meant to establish that Chu-gu-an had freely ceded territory to the Russians and joined them in a military alliance. In making such a claim company officials carefully reframed their history of prior interactions with the Kashaya Pomos and the Coast Miwoks, construing them as a legal transfer of land.

Russian-American Company officials presented the protocol as the record of a single day's events. Behind the document, however, was a history of interactions with Native Americans in the region that went back years. Russian-led colonization of the central California coast began around 1806 at the behest of company officials who hoped to establish a base for hunting sea otters and supplying Alaskan outposts with produce. The first Russians came to the region as leaders of hunting parties seeking new sources of otter furs after overhunting in Alaska had wiped out north Pacific rookeries. These expeditions lacked the means to construct a colony, but Aleksandr Baranov, the chief manager (or governor) of the Russian-American Company, saw them in part as scouting expeditions for permanent occupation. ${ }^{16}$ Meanwhile, these ventures established diplomatic relationships first with the Bodega Miwoks and later with the Kashaya Pomos who occupied Métini. ${ }^{17}$

This diplomatic approach was motivated in part by military considerations. The Russian-American Company was too weak to conquer California's Native American population by force as they had the Alaskan Aleuts and Tlingits. The Russians also worried about military resistance such as the Tlingits had mounted in $1804-05,{ }^{18}$ prompting the company to seek peaceful coexistence with coastal Native Americans. In an 1806 account of a fleeting encounter with Native Americans in Bodega Bay, Imperial

15. Potekhin, "Selenie Ross," 21. See also Sir Francis Drake, The World Encompassed by Sir Francis Drake . . (London, 1628), 80.

16. $R C, 1: 246-47,264-69$.

17. Gibson and Istomin, "Introduction," in $R C, 1: 1-23$.

18. See Black, Russians in Alaska; Grinev, The Tlingit Indians in Russian America; Dauenhauer et al., Anóoshi Lingit Aaní Ká. Yu. F. Lisyanskiy, a Russian traveler, recorded and published an account of one treaty of military alliance between Russians and a toyon (indigenous leader) at New Archangel in 1805 in terms that anticipated the 1817 Fort Ross Treaty. Yu. F. Lisyanskiy, Puteshestviye vokrug sveta v 1803, 4, 5, i 1806 godakh . . ., vol. 2 (St. Petersburg, 1812), 115-17. 
Chamberlain Nikolay Rezanov wrote to Foreign Affairs Minister Nikolay Rumyantsev that a naval officer had "met four [Native Americans] who were fishing among the rocks" and "treated them kindly," giving them "trifling presents" before having them "dressed and presented to the governor." ${ }^{19}$ Likewise, Baranov's instructions for an 1811 expedition ordered Assistant Governor Ivan Kuskov to "mollify all of [the Native Americans] with as peaceable and as friendly an appearance and reception as possible" and to "indulge rudeness." 20 Diplomatic outreach was intended to avoid military confrontation; documentation would show imperial ministers that the company was doing everything it could to avoid a repeat of the war in Alaska.

The diplomatic approach also gave the Russian-American Company a way to claim land rights. Since the region they targeted for colonization theoretically lay within Spanish and U.S. purview, land rights were just as important to the colony's survival as peace with coastal tribes. Company accounts presented early contacts with Native Americans as acts of land acquisition. In the spring of 1807 Timofey Tarakanov led a party of Aleut hunters to Bodega Bay, where he briefly established a base and made contact with the Bodega Miwoks. By way of diplomatic outreach, Tarakanov claimed to have acquired temporary rights to land. ${ }^{21}$ Then an 1808-09 expedition led by Kuskov made contact with a Bodega Miwok leader who helped the Russians locate sea otters. Kuskov gave unnamed Native Americans (no doubt including the Bodega Miwok leader he met) "beads, pebbles, dresses, and some iron knick-knacks" as well as "silver medals with the inscription 'Allies of Russia' to wear around their necks." ${ }^{22}$ And when Kuskov traveled to the region again in early 1811, Baranov gave him thirty

19. $R C, 1: 215$.

20. $R C, 1: 285$.

21. Tarakanov's account is described in K. T. Khlebnikov, Notes on Russian America, part 1, Novo-Arkbangel'sk, trans. Serge LeComte, ed. Richard A. Pierce (Kingston, Ontario: Limestone Press, 1994), 9. Mariano Payeras, a Franciscan missionary, reported in 1822 that he spoke to Bodega Miwok converts at San Rafael who told him that the commander of a Russian ship named Talacani (possibly referring to Tarakanov) "stopped at Ross, and bought that place from its chief, Panac:úccux" (Payeras, Writings of Mariano Payeras, 335). Payeras also mentioned that the Russians purchased part of Bodega Bay around the same time as Ross. The details of this account should be treated with skepticism since Payeras was a Spanish rival of Russia. For an account of Payeras's importance as a source for the history of Russian colonization, see Glenn J. Farris, "Talacani, the Man who Purchased Fort Ross," Fort Ross Interpretive Association Nerwsletter, September-October 1993, [7-9].

22. $R C, 1: 275$, quotation 1:288. 
newly minted silver medallions as well as twenty old tin medallions to "confer ... only upon the elders of those places where you are quartered, as well as those of Bodega Bay and those who come from distant mainland [interior] places and bays, with a record of their abodes and names," an indication that the company had claimed those places. ${ }^{23}$ On a third expedition at the end of 1811, Kuskov also "met some of the native leaders and gave them medals and gifts, for which they agreed to surrender voluntarily the area that he needed for settlement," by which he apparently meant Métini, located some twenty miles north of the previous contact site at Bodega Bay. ${ }^{24}$ The Kashaya Pomos apparently gave the company permission to stay. By August 1812 work was underway on the Ross colony, where the company built a fort and adjoining settlement. ${ }^{25}$

Though there is no reason to doubt that Russians made a diplomatic approach to the Coast Miwoks and Kashaya Pomos, Russians almost certainly misrepresented how Native Americans viewed such interactions. Pomo- and Miwok-speaking groups did not trade land rights for payment in the way the Russians implied. From their perspective exchanges of goods were social and political in nature and helped maintain ties between different kin groups and tribes. The Coast Miwoks and the Kashaya Pomos lived in village clusters connected by a common language, cultural practices, and kinship ties. They maintained these ties in gatherings where tribal members met to give gifts and play games for objects such as beads, baskets, and blades. Such gatherings reinforced a sense of shared identity among speakers of the same language. They were also important in maintaining links between different tribes: tribes and kin groups exchanged goods in an ongoing process that consolidated political and kinship ties as well as the prestige of leaders who acquired and circulated valued items. ${ }^{26}$ Since Sir Francis Drake's coastal exploration in the sixteenth century, the Coast Miwoks had collected European- and Asian-made goods and circulated them in exchange gatherings among themselves and probably among other tribes. ${ }^{27}$

23. $R C, 1: 281$ (brackets in original); Khlebnikov, Notes on Russian America, 11.

24. Tikhmenev, A History of the Russian-American Company, 133.

25. The precise date of the fort's construction is unknown. For a discussion of the uncertainty in the records, see Gibson and Istomin, "Introduction," in $R C$, 1:21-23.

26. Lightfoot, Native Americans, Missionaries, and Merchants, 45.

27. For Coast Miwoks' acquisition of artifacts from Drake's anchorage and their trade with other tribes after the colonial era, see Mary E. T. Collier and Sylvia Barker Thalman, eds., Interviews with Tom Smith and Maria Copa: Isabel Kelly's Ethnographic Notes on the Coast Miwok Indians of Marin and Southern Sonoma Coun- 
Native Americans probably saw Russian gifts in these terms-as establishing social or political links. One piece of evidence is that in excavations of the communities in closest contact with the Russians, archaeologists have not found hoards or collections of Russian- and Asian-made goods, suggesting that Native Americans traded Russian items inland. ${ }^{28}$ When they gave gifts to coastal leaders, Russians were joining-perhaps at first unknowingly — an expansive system of trade stretching along the coast and inland, one used to keep up relations rather than pay for property rights.

Further evidence of how the Kashaya Pomos in particular viewed Russians can be found in tribal histories of Russian colonization. In 1958 Herman James, a Kashaya Pomo speaker, related a tradition about Russian colonization: "Having landed, [the Russians] built their houses close to where the Indians were. After staying for a while, they got acquainted with them. They stayed with them. The Indians started to work for them. They lived there quite a while; having lived there for thirty years, they returned home."29 Although James's story from 1958 cannot be taken to reflect Chugu-an's views from 1817, it does show that Kashaya Pomos had a tradition of viewing Russian occupation as a "stay" in the region, albeit one that lasted "quite a while." Such an acknowledgment of mutual acquaintance and peaceful proximity was certainly not the same as the "purchase" and later "cession" of land that Russians described, nor was it a recognition of rights of indefinite occupation. Yet despite Russian misrepresentation of exchanges with tribal leaders, company officials clearly had reached some kind of mutual understanding with the Coast Miwoks and the Kashaya Pomos. Neither group attempted violent resistance. By the time of the 1817 meeting with Chu-gu-an, Gem-le-le, Amat-tan, and other leaders, the Russians had established some measure of acceptance of their presence, in part by handing out gifts.

\section{ROSS UNDER INTERNATIONAL LAW}

As company officials made peace with Native Americans, they faced obstacles at home. ${ }^{30}$ The first concerned Ross's founding. Russian-American

ties, California (San Rafael, Calif.: Miwok Archeological Preserve of Marin, 1991), 77, 203-04, 354-58.

28. Lightfoot, Native Americans, Missionaries, and Merchants, 175.

29. Herman James, "Tales of Fort Ross," as told to Robert L. Oswalt, September 1958, in Robert L. Oswalt, ed., Kashaya Texts (Berkeley: University of California Press, 1964), 277.

30. For the administration of the Russian-American Company, see Basil Dmytryshyn, "The Administrative Apparatus of the Russian-American Company, 1798-1867," Canadian-American Slavic Studies 28, no. 1 (1994): 1-52; A. N. Yer- 
Company officials colonized Métini without permission from the czar, which left them free to choose a location but deprived them of the czar's support in justifying the colony's legality to foreign rivals. Their predicament in this regard can be glimpsed in Foreign Affairs Minister Rumyantsev's response to a letter from the Russian-American Company board of directors requesting "imperial protection for the settlement undertaken in New Albion in case the American [United] States, from envy should do something." ${ }^{11}$ In a reply Rumyantsev offered a pro forma reassurance of "imperial protection" but stated that the czar refused "to have the state undertake a settlement" 32 - meaning that although the czar would not order the colony to be abandoned, nor could the company rely on imperial diplomats to publish arguments for its legality as they could have in the case of a colony built on the czar's orders. It was therefore incumbent on Ross officials to explain to skeptical ministers in St. Petersburg their legal justification for colonizing this particular piece of land.

The difficulty in proving the legality of their claim to the czar was related to a second obstacle that faced company officials-clearing their title against Spain. Though the company had once feared an attack from the United States, that never came to pass. ${ }^{33}$ Spain, however, asserted its rights with

molayev, "Glavnoye pravleniye Rossiyskoy-Amerikanskoy Kompanii: sostav, funktsii, vzaimootnosheniya s pravitel'stvom, 1799-1871," in Amerikanskiy yezhegodnik 2003 (Moscow: Nauka, 2005), 271-92; and A. V. Grinev, "Rol' gosudarstva v obrazovanii Rossiysko-Amerikanskoy kompanii," in A. O. Chubar'yan et al., ed., Russkoye otkrytiye Ameriki (Moscow: ROSSPEN, 2002), 437-50. For the formation of the company see, A. Yu. Petrov, Obrazovaniye Rossiysko-Amerikanskoy Kompanii (Moscow: Nauka, 2000). For a broader history of Russia in America, see V. P. Petrov, Russkiye v istorii Ameriki (Moscow: Nauka, 1991).

31. $R C, 1: 276$.

32. $R C, 1: 276$. This is a model of colonialism that Okun has referred to as "camouflaged expansionism" (Okun, The Russian-American Company, 125).

33. $R C, 1: 276$. For an account of the influence of U.S. activities on Russian settlement in California, see Okun, The Russian-American Company, 121-22. On the role of the Russian-American Company in Russia's imperial rivalry with the United States, see Howard I. Kushner, Conflict on the Northwest Coast: AmericanRussian Rivalry in the Pacific Northwest, 1790-1867 (Westport, Conn.: Greenwood Press, 1975). Despite being rivals with the United States in the Northwest, Russians also cooperated with American shipping concerns in the fur trade. See A. A. Istomin, "Sovmestnyye Russko-Amerikanskiye promyslovyye ekspeditsii v Kaliforniyu (1803-1812 gg.)," Voprosy istorii 8 (1998): 105-13; and E. W. Giesecke, "Unlikely Partners: Bostonians, Russians, and Kodiaks Sail the Pacific Coast Together, 1800-1810," Mains'l Haul: A Journal of Pacific Maritime History 43, nos. 3-4 (2007): 34-69. 
much greater menace: Spanish colonists confronted Ross officials directly, and Spanish diplomats in St. Petersburg protested the colony's existence to the Russian government. ${ }^{34}$

At the basis of Spain's protests was a competing theory of colonial land rights. Historically, Spain based its rights to North America on its supposed "discovery" of the hemisphere in 1492 and papal bulls donating the Americas to the Spanish crown. As a basis for possession, the doctrine of discovery held that a party who found a piece of land without an owner had the right to take it..$^{35}$ This doctrine held that Native Americans did not own the lands they inhabited either because they were infidels or because they did not understand land ownership. Despite having largely abandoned rights of discovery in the North Atlantic world, Spain sporadically invoked such claims in contests over the Pacific coastline through the early nineteenth century, citing discovery to claim Nootka Sound as well as Ross. ${ }^{36}$ Although Spain had not in any way settled or colonized the area north of San Francisco, Spanish officials still viewed it as theirs and maintained to Russians that

34. For the rivalry with Spain on the Pacific coast, see Alexei A. Istomin, "Osnovaniye kreposti Ross v Kalifornii v 1812 g. i otnosheniya s Ispaniyey," in Bolkhovitinov, Istoriya Russkoy Ameriki, 2:190-274; and Diane Spencer Pritchard, "Joint Tenants of the Frontier: Russian-Hispanic Relationships in Alta California" in Russian America: The Forgotten Frontier, eds. Barbara Sweetland Smith and Redmond J. Barnett (Tacoma: Washington State Historical Society, 1990), 81-93. For broader context, see N. N. Bolkhovitinov, "Russian America and International Relations," in S. Frederick Starr, ed., Russia's American Colony (Durham, N.C.: Duke University Press, 1987), 251-70; and Dominic Lieven, Empire: The Russian Empire and Its Rivals (New Haven: Yale University Press, 2000).

35. Andrew Fitzmaurice, "Discovery, Conquest, and Occupation of Territory," in Bardo Fassbender and Anne Peters, eds., The Oxford Handbook of the History of International Law (Oxford: Oxford University Press, 2012), 841. For more on discovery, see Robert A. Williams, The American Native American in Western Legal Thought: The Discourses of Conquest (New York: Oxford University Press, 1990), 74-118. For the English use of this doctrine, see Robert J. Miller et al., Discovering Indigenous Lands: The Doctrine of Discovery in the English Colonies (New York: Oxford University Press, 2012). For its use in U.S. history, see Lindsay G. Robertson, Conquest by Law: How the Discovery of America Dispossessed Indigenous Peoples of Their Lands (New York: Oxford University Press 2005).

36. On Nootka Sound, see Daniel Clayton, Islands of Truth: The Imperial Fashioning of Vancouver Island (Vancouver: University of British Columbia Press, 2011), 184-85. For an account of Russia's involvement in the area, see M. S. Al'perovich and N. N. Bolkhovitinov, "Nutka-zundskiy krizis i oslableniye rossiysko-ispanskogo sopernichestva na Severo-Zapade Ameriki," in Bolkhovitinov, Istoriya Russkoy Ameriki, 1:295-304. For Spanish use of discovery to protest Ross, see Potekhin, “Selenie Ross," 26. 
they had exclusive rights as far north as the Strait of Juan de Fuca. ${ }^{37}$ Their claim to the coast immediately north of San Francisco in particular was strengthened by the fact that Bodega Bay was named after the Spanish naval officer, Juan Francisco de la Bodega y Quadra, who mapped and described the area in $1775 . .^{38}$

Initially European politics constrained Spanish protests against Ross. In 1812 Russia and Spain signed the Treaty of Velikiye Luki, making the two countries allies against Napoleon Bonaparte. To stay on good terms with Russia, the Spanish crown took a cautious approach to Ross, ordering the viceroy in Mexico City "to show extreme delicacy in carrying out the liquidation of the Russian settlement without damaging friendly relations between the two countries." ${ }^{39}$ Thus, Spanish officials in Alta California were at first relatively polite in their protests. ${ }^{40}$ The defeat of Napoleon, however, freed the Spanish to be more aggressive. ${ }^{41}$ On February 10, 1817, the crown ordered officials of New Spain to destroy Ross. ${ }^{42}$ In April 1817 Zea Bermúdez, the Spanish ambassador in St. Petersburg, wrote to the Russian foreign minister demanding that the Russian-American Company "abandon a venture [Ross] that is incompatible with the state of peace and the alliance existing between Russia and Spain," adding that company officials had "illegally occupied" the area. ${ }^{43}$ On June 23,1817 , the crown reiterated its order for destruction and colonial officials expressed their willingness to carry it out. ${ }^{44}$ Though there is no evidence that the Russians knew about the order, Bermúdez's public remonstrance was menacing enough.

In response to Spanish protests Hagemeister convened the September

37. $R C, 1: 311$.

38. The authoritative account of this figure is Freeman M. Tovell, At the Far Reaches of Empire: The Life of Juan Francisco de la Bodega y Quadra (Vancouver: University of British Columbia Press, 2008).

39. A. I. Sizonenko and M. Ortega, Rossiya i Meksika v pervoy polovine XIX v. (Moscow: Academy of Sciences of the USSR, 1989), 21.

40. For the details of some of these protests, see $R C, 1: 295,310-11$. The fact that Spanish officials protested the settlement while Spanish colonists negotiated trade deals suggests that the protests were perfunctory rather than serious.

41. For this context, see Bolkhovitinov, Russko-Amerikanskiye otnosheniya, $140-44$.

42. Mathes et al., The Russian-Mexican Frontier, 108.

43. $R C, 1: 315$.

44. Mathes et al., The Russian-Mexican Frontier, 108. Spanish fears of Ross may have been heightened by Americans spreading rumors that Russians wanted to destroy Spanish possessions. See Potekhin, "Selenie Ross," 17. 
22, 1817, meeting. Since company officials had received Kashaya Pomo permission to stay years before, the meeting itself was not really about making any new agreement with tribal leaders. Rather, it was meant to create a paper trail that would prove the company's rights to Russia and Spain. The company drafted the protocol in an attempt to shift the legal framework of the dispute about Métini from discovery-where Spain undoubtedly had priority - to cession, or transfer of territory with an owner.

\section{FROM DISCOVERY TO CESSION: NATIVE AMERICAN CONSENT AND INTERNATIONAL LAW}

Ironically, the Russian-American Company's attempt to claim land by cession had roots in the writings of Spanish jurists, who were the first to critique land rights based on discovery and defend contracts with indigenous inhabitants. The first prominent European critic of discovery was the Spanish jurist Francisco de Vitoria, who questioned the 1493 papal bulls awarding the Americas to Spain. Vitoria disputed the Spanish crown's act of claiming the Americas based on discovery, arguing that inhabitants already occupying a territory had rightful ownership of it even if they were not Christians. According to Vitoria, all people possessed natural rights regardless of their religion or culture, giving the inhabitants of the Americas full title to their land. "[B]arbarians possessed true public and private dominion," he wrote, ${ }^{45}$ meaning that discovery "provides no support for possession of these lands, any more than it would if they had discovered us." 46 Since a rightful owner already possessed the land, the pope had no right to give it to Spain.

Vitoria's arguments about the legal standing of "barbarians" profoundly influenced later international law. ${ }^{47}$ One consequence of his claim was that

45. Francisco de Vitoria, On the American Indians, in Anthony Pagden and Jeremy Lawrance, eds., Political Writings (New York: Cambridge University Press, 1991), 264. To the objection that Native Americans were "madmen" and could not own their land, Vitoria wrote that "they have some order (ordo) in their affairs: they have properly organized cities, proper marriages, magistrates and overlords (domini), laws, industries, and commerce, all of which," like land ownership, "require the use of reason." See Vitoria, On the American Indians, 250.

46. Vitoria, On the American Indians, 265.

47. As Hugo Grotius wrote, "In considering treaties, the question is often asked, whether it is lawful to make them with persons who are strangers to the true religion." He concluded there was "no doubt" it was lawful. See Hugo Grotius, The Law of War and Peace, trans. Louise R. Loomis (Roslyn, N.Y.: Walter J. Black, 1949), 171. The question of European treaties with infidels was mostly debated in the context of military alliances. See Richard Tuck, "Alliances with Infidels in the European Imperial Expansion,” in Sankar Muthu, ed., Empire and Modern Political 
European explorers could acquire land by contract with its inhabitants. If Europeans could not seize land by force, they could come to an agreement with its owners, a procedure described by numerous authorities in Vitoria's wake. In 1797, for example, the German philosopher Immanuel Kant asserted that even in cases of "shepherds or hunters . . . who depend for their sustenance on great open regions, [European] settlement may not take place by force but only by contract." ${ }^{48}$ This vision of "empire by treaty" offered a way for colonial officials to claim rights to land by documenting its acquisition from Native Americans. ${ }^{49}$

Claims based on contracts and treaties, however, also raised questions about Native Americans' consent to such agreements. By the eighteenth century most legal authorities agreed in theory that Native Americans owned their territory, but they wondered whether colonists' dominance over indigenous people and control of written documents made Native Americans' agreement to contracts and treaties all but meaningless. Kant, for example, argued that colonial purchase of land was valid only if it "does not take advantage of the ignorance of those inhabitants with respect to ceding their lands." ${ }^{50}$ Although they acknowledged indigenous consent as a theoretical basis for land acquisition, some authorities doubted that it was always valid in practice, believing that colonization was rife with deceit and violence and that paper records hardly guaranteed the legality of an agreement made thousands of miles away. ${ }^{51}$

While western Europeans debated the rights of colonial occupation, Russian imperialists developed procedures of their own for conquering foreign

Thought (New York: Cambridge University Press, 2012), 61-83. For Vitoria's role in the history of theories of legal relations between Europeans and indigenous nations, see Anghie, Imperialism, Sovereignty and the Making of International Law, 13-31.

48. Immanuel Kant, "The Metaphysics of Morals," in Practical Philosophy, trans. and ed. Mary J. Gregor (New York: Cambridge University Press, 1996), 490.

49. For a general overview of this concept, see Saliha Belmessous, "The Paradox of an Empire by Treaty," in Empire by Treaty: Negotiating European Expansion, 1600-1900, ed. Saliha Belmessous (New York: Oxford University Press, 2014), 1-18. For an account of North American land agreements between settlers and Native Americans, which differed profoundly from those described by contemporaneous legal theorists, see Banner, How the Indians Lost Their Land.

50. Kant, "The Metaphysics of Morals," 490.

51. See Pitts, Boundaries of the International. For an account of how criteria of rightful occupation were used to critique colonial endeavors in the English-speaking world, see Andrew Fitzmaurice, Sovereignty, Property and Empire, 1500-2000 (Cambridge: Cambridge University Press, 2014). 
lands. In the early modern era Russian protocols for acquiring territory were more limited than those employed by clashing European empires. Whereas European colonial treaties often recognized Native American polities as sovereign entities ceding land to European crowns, Russian colonial documents portrayed conquered powers as offering allegiance to the czar, an act deriving from imperial rituals of submission rather than theories of natural rights. ${ }^{52}$ Russian imperialists made claims to Siberia (from the sixteenth century onward), the Caucasus (from the mid-eighteenth century onward), and Central Asia (from the mid-nineteenth century onward) by documenting subjugated leaders' acts of fealty.

In the eighteenth century, however, Russian jurists began to circulate European legal texts in Baltic and Russian universities. Starting with Peter the Great and continuing during Catherine the Great's reign, Russian scholars translated and commented on works of natural law and published treatises about the law of nations. ${ }^{53}$ Many of these works emphasized the

52. For Russian treaties with non-Christian people, see Michael Khodarkovsky, Russia's Steppe Frontier: The Making of a Colonial Empire, 1500-1800 (Bloomington: University of Indiana Press, 2002), esp. 39-45, 51-56, and 135-39. See also Michael Khodarkovsky, “'Ignoble Savages and Unfaithful Subjects': Constructing Non-Christian Identities in Early Modern Russia," in Daniel R. Brower and Edward J. Lazzerini, eds., Russia's Orient: Imperial Borderlands and Peoples, 17001917 (Bloomington: University of Indiana Press, 1997), 9-26. For imperial Russian relations with Muslim polities, see Robert D. Crews, For Prophet and Tsar: Islam and Empire in Russia and Central Asia (Cambridge: Harvard University Press, 2006), esp. 42, 45, 241-42. Willard Sunderland, Taming the Wild Field: Colonization and Empire on the Russian Steppe (Ithaca: Cornell University Press, 2004) focuses less on treaties but provides useful context. Europeans used submission and loyalty oaths as well; for example, see Jenny Hale Pulsipher, Subjects unto the Same King Indians, English, and the Contest for Authority in Colonial New England (Philadelphia: University of Pennsylvania Press, 2005). For a broader survey of Russian foreign affairs including treaty relations, see John P. LeDonne, The Russian Empire and the World, 1700-1917: The Geopolitics of Expansion and Containment (New York: Oxford University Press, 1997). For an account of Russian diplomatic relations with Britain, see Matthew P. Romaniello, Enterprising Empires: Russia and Britain in Eighteenth-Century Eurasia (New York: Cambridge University Press, 2019).

53. See V. E. Grabar, The History of International Law in Russia, 1647-1917, trans. and ed. W. E. Butler (Oxford: Clarendon Press, 1990), 33-215; and Lauri Mälksoo, Russian Approaches to International Law (Oxford: Oxford University Press, 2015). See also William E. Butler, "Treaty Collections in Eighteenth-Century Russia: Encounters With European Experience," in A. G. Cross, ed., Russia and the 
importance of consent in treaties with lesser powers. By some accounts Russians could make treaties with any foreign power regardless of race or religion, as long as they secured consent. As V. T. Zolotnitskiy, the author of the first Russian treatment of the law of nations, put it, "the essence of a treaty is the consent of both parties, which should be just, without regard to distinction of peoples." ${ }^{4}$ Zolotnitskiy's conclusion echoed Vitoria's argument from centuries before that non-Christian peoples had the natural right to make agreements and cede land to outsiders. More importantly for the Russian-American Company, it also gave Russians a way to acquire land from such peoples without the need to rule them as subjects.

\section{VERIFYING NATIVE AMERICAN CONSENT: FROM CESSION TO MILITARY ALLIANCE}

When documenting interactions with the Kashaya Pomos and the Coast Miwoks, Russian-American Company officials used theories from international law which held that Christian powers could acquire land by contract with Native American owners. The purpose of the 1817 meeting at Ross was to dramatize a tribal leader ceding land to company officials as his natural right. Notably, the company did not document the meeting in the form of a treaty, the genre typically used by Spain, the United States, and other imperial powers to record agreements with each other; instead they drafted a protocol, a format most often employed in meetings between diplomats. ${ }^{55}$ One reason for this was that Russian negotiators were acting as company officials, not diplomats of the imperial government. They had little discretion to make an agreement on the czar's behalf. By using a protocol, company officials stayed carefully within their bounds. A protocol also sent the signal that the Russian-American Company did not regard tribal leaders as fully sovereign or "treaty-worthy." ${ }^{56}$ Whereas a treaty implied that signatories were somehow equal, a protocol sent no such message.

Using a protocol also enabled company officials to bypass the crucial question of Native Americans' understanding of written treaties. According

West in the Eighteenth Century (Newtonville, Mass.: Oriental Research Partners, 1983), 249-58.

54. Quoted in Grabar, The History of International Law in Russia, 196.

55. For a discussion of this point, see Gibson and Istomin, "Introduction," in $R C, 1: 118-19$. For examples of the company's use of protocols, see $R C, 1: 310-11$.

56. On "treaty-worthiness" see Eliga H. Gould, Among the Powers of the Earth: The American Revolution and the Making of a New World Empire (Cambridge: Harvard University Press, 2012), 11-13. 
to most legal theory, understanding was a necessary component of consent. ${ }^{57} \mathrm{~A}$ party could not consent to an agreement without an understanding of its terms. This had already been a problem for Russian-American Company officials in Hawaii. In 1816, the company had signed a treaty agreement with Kaumuali'I, the chief of Kaua'I, but there was controversy over whether he understood it. ${ }^{58}$ The protocol avoided this problem. Rather than having to secure an " $\mathrm{x}$ " or written symbol to express Native Americans' consent, company officials attributed direct speech to tribal leaders, quoting the Native Americans' own words to show that the tribal leaders understood the agreement. And according to the Russians' account, those words confirmed a simple transaction: land for military alliance.

In terms of international law, Russian transcriptions of Chu-gu-an's words and gestures confirmed a gift of land to the Russians. The Métini protocol resembled, in part, what the legal scholar R.Y. Jennings has called a "treaty of cession," which performs "the transfer of territorial sovereignty by one State to another State." ${ }^{\text {99 }}$ Treaties of cession were familiar instruments in European diplomacy, as states and principalities redrew territorial maps in the wake of eighteenth-century wars. They were also common instruments of colonization and settlement, as colonial states and later the United States used treaties to claim rights to Native Americans' land. ${ }^{60}$

In the Métini protocol, however, the Russian-American Company adapted the language of cession treaties to give the company's negotiations with Native Americans the appearance of a legally valid agreement. The protocol began by focusing on Chu-gu-an's disposal of Métini. "CaptainLieutenant Hagemeister thanked [the assembled Native American leaders]

57. For an account of this idea as it relates to indigenous groups, see Cathal M. Doyle, Indigenous Peoples, Title to Territory, Rights and Resources: The Transformative Role of Free Prior and Informed Consent (New York: Routledge, 2015).

58. See Mills, Hawai'i's Russian Adventure, 25, 28-29; and Pierce, Russia's Hawaiian Adventure, 72.

59. R. Y. Jennings, The Acquisition of Territory in International Law (Manchester, U.K.: Manchester University Press, 1963), 16.

60. For an account of English-language treaties of cession in North America, see Daniel K. Richter, “'To Clear the King's and Indian's Title': Seventeenth-Century Origins of North American Land Cession Treaties," in Belmessous, Empire By Treaty, 45-77. See also Allan Greer, "Dispossession in a Commercial Idiom: From Indian Deeds to Land Cession Treaties," in Juliana Barr and Edward Countryman, eds., Contested Spaces of Early America (Philadelphia: University of Pennsylvania Press, 2014), 69-92. For a broader account of land transfer from tribes to colonists, see Banner, How the Indians Lost Their Land. For the complexity of treaties between colonists and Native Americans who spoke different languages, see Calloway, Pen and Ink Witchcraft. 
on behalf of the Russian-American Company for the cession [ustupka] of the land for the fort, buildings, and facilities - a site belonging to Chugu-an and called Med-zhy-ny by the inhabitants," it opened. This language sought to establish Chu-gu-an's transfer of rights to the company as a legal fact, showing that he had freely ceded the land and sovereignty over it to the Russians in a manner consistent with natural rights. The protocol also tried to show Chu-gu-an's prior ownership of the land, a prerequisite of his right to give it to the Russians. Ross was on "a site belonging to Chugu-an," at least formerly, and the Russians included the name for the site, Med-zhy-ny (Métini), trying to show that the Kashaya Pomos previously occupied and owned it. Finally, Hagemeister "thanked" all of the assembled Native Americans—not just Métini's supposed owner, Chu-gu-animplying widespread consent on the part of surrounding groups to Russian occupation. According to the protocol, Chu-gu-an had lawfully ceded the land to the Russians and no one had objected. ${ }^{61}$

Despite the seeming finality of Chu-gu-an's cession, company officials were well aware that it did not immediately translate into Russian rights. To skeptical readers in Russia and other imperial governments, Chu-gu-an's act conceivably raised the question of why he would have given up so much for so little. It also left unexplained how nearby Native American leaders not included in the gathering might have viewed the matter. The Métini protocol tried to resolve these issues by portraying Chu-gu-an's cession of land as an attempt to secure Russian military protection, thus providing Kashaya Pomo and other tribal leaders a rationale for giving up the land to the Russians.

According to the protocol, Chu-gu-an gave up Métini because he wanted Russian protection. After thanking the chief for the gift, Hagemeister "stated that he hoped that [the Native Americans] would have no reason to regret the proximity of the Russians." In response, "Chu-gu-an, as well as Amat-tan, whose residence was also not distant, answered 'that they are very pleased with the occupation of the site by the Russians, that they now live in security against other Indians, who formerly attacked them, and that this security began only from the time of the settlement.' "62 Chu-gu-an ceded the land, the Russians explained, because he wanted their help against enemy Indians. Thus, he had a reason to give it away. This explanation, however, does not match any extant description of Kashaya Pomos' conflicts with other Native Americans from the time period. Russian-American

61. $R C, 1: 322$.

62. $R C, 1: 322$. 
Company records and twentieth-century oral traditions both documented revenge killing involving Kashaya Pomos, but not military peril. ${ }^{63}$ There is no evidence, outside the protocol, that Kashaya Pomos were waging a defensive struggle against enemy tribes. A possible explanation for the discrepancy is that, in order to supply a plausible motivation for Chu-gu-an's cession of land, Ross officials mistook or deliberately misconstrued coastal practices of revenge killing as a military threat from other Native Americans. One piece of evidence for this interpretation is that Russians did indeed intervene to stop revenge killing, apparently largely putting a halt to the practice. ${ }^{64}$ Revenge killing, however, was usually governed by a sense of reciprocity and did not resemble the open military conflict described in the protocol.

A more probable explanation is that $\mathrm{Chu}-\mathrm{gu}-\mathrm{an}, \mathrm{Amat}-\mathrm{tan}$, and $\mathrm{Gem}-$ le-le had in fact sought out Ross for protection from Spanish-led slave raiders, who ranged as far north as Bodega Bay. ${ }^{65}$ If this explanation is correct, the protocol accurately reported the tribal leaders' motive for gathering at the fort, but altered the nature of the threat to avoid offending Spain. ${ }^{66}$ In their internal correspondence, Russian-American Company officials often emphasized Spanish violence against Native Americans as a justification for occupying land north of the Spanish colonies. In the 1806 report to Rumyantsev, Imperial Chamberlain Rezanov portrayed the Spanish as brutally subjugating Native Americans. "[T]he missionaries in California have completely enslaved their neophytes," he wrote. "[The Native American's] advantages are forgotten, the brawn and brain of his kin are converted to cattle, his spirit is killed forever." ${ }^{77}$ Company correspondence likewise portrayed Native Americans' fear and hatred of the Spanish. "[Russian scouts] met several natives," one report read, "who, taking them for Spaniards, would have attacked them but, recognizing that they were not, readily let them pass." ${ }^{68}$ Other reports claimed that Native Americans were "hunted

63. For Russian records of coastal revenge killing, see $R C, 1: 456-57$. For Kashaya Pomo accounts of such practices, see Herman James, "Brothers Avenge the Death of Their Sister," as told to Robert L. Oswalt, September 1958, in Oswalt, Kashaya Texts, 241-45; and James, as told to Oswalt, September 1958, "The Last Vendetta," in Oswalt, Kashaya Texts, 255-59.

64. James, "The Last Vendetta."

65. $R C, 1: 398$.

66. For this theory, see $R C, 1: 322 \mathrm{n} 4$.

67. $R C, 1: 226$.

68. Ibid., 1:288. 
like animals" and "attack the Spaniards as enemies." ${ }^{69}$ Yet company officials omitted any mention of such matters in the protocol. Spanish diplomats obviously would not have accepted a litany of Spanish crimes as a justification for Russian colonization, nor could Russian imperial ministers in St. Petersburg have been expected to relay such justifications to their Spanish counterparts. Moreover, both Russian and Spanish foreign ministers might have viewed a military alliance between the Russian-American Company and Native Americans against the Spanish as cause to eliminate the colony. In describing Chu-gu-an's rationale, the company therefore substituted a Native American threat for a Spanish one, giving Chu-gu-an and the other leaders a reason for accepting Russian help without risking offense to Spanish officials.

Despite emphasizing military aid as the basis of the Russian-American Company's friendship with the Kashaya Pomos and the Bodega Miwoks, in reality the company did little to protect Native Americans from Spanish incursions. A report from a Russian imperial naval officer visiting Ross shortly after the 1817 meeting noted mockingly that when "Spaniards extend their hunting of men as far as Great Bodega itself . . . all of the Indian tribes assemble under the cannons of Ross or at the harbour of Rumyantsev, where they think that 4 falconets and three Russians are able to defend them from the Spaniards." ${ }^{\text {70 }}$ This suggests that those gathered at Ross on September 22, 1817, may have been fleeing a Spanish-led slavetrading raid. The officer also provided information that contradicted the protocol's claims about Russian military aid to Native Americans, recounting that in 1817, "when many [Native American refugees from the Spanish] gathered at Slavyansk and requested its protection, [Kuskov] persuaded them to keep to the woods and ravines in the hills and then attack the Spaniards by surprise. The savages listened to him and then took to the woods that are visible on the Great Bodega side of Rumyantsev Harbour." ${ }_{11}$ Though this gathering may have been prompted by the Spanish construction of Mission San Rafael in 1817, and possibly occurred before the military alliance announced in the protocol, Kuskov's instructions to the refugees suggest that he expected them to protect the Russians, not the other way around.

However untrue, the protocol's account of a defensive alliance served the

69. Ibid., 1:377, 318.

70. $R C, 1: 398-99$.

71. $R C, 1: 399$. 
purpose of explaining Chu-gu-an's rationale for ceding Métini to the Russians, a crucial part of verifying his consent. As the protocol had it, Chugu-an gave the company the land so he and his people could enjoy the protection of the fort. Crucially, the protection was the fort itself, not any Russian troops deployed beyond the colony-an important distinction given the lack of manpower at Ross and the concern that company involvement in Native American wars would have caused the imperial government. Company officials wanted to show imperial ministers that Chu-gu-an thought he was getting something in return for the land, when in reality they were giving him little.

In the protocol's telling, company officials clinched the alliance by awarding a medal to $\mathrm{Chu}$-gu-an. After an "agreeable response" to Russian inquiries about land claims, "the chiefs and others presented gifts, and the foremost of them, Chu-gu-an, was presented with a silver medallion adorned with the Russian imperial coat of arms and the inscription 'Allies of Russia', and it was stated that this gave him the right to respect from the Russians because without it they need not come to [help] him, and that it imposed upon him the obligation of solidarity and assistance should the occasion require it; both he and the others declared their willingness and expressed their thanks for the reception." 72

Whereas the act of land cession previously described in the protocol derived from natural rights, the ritual of awarding a medal had quite different roots: it was a common ceremony by which imperial powers recognized loyal subjects. Like many imperial powers, Russia had used award medals to portray Native Americans as loyal allies of the czar. During I. I. Billings's voyage to the Aleutian Islands in 1791, Catherine the Great had instructed him to distribute gold, silver, and copper medals to Alaska Native leaders "as a symbol of the customary friendship of the Russians toward them," as a 1785 decree put it. ${ }^{73}$ However, though this instruction sounded like an attempt to secure political subjection — and had been used in exactly such a

72. $R C, 1: 322$.

73. A. I. Alekseyev et al., Russkiye ekspeditsii po izucheniyu severnoy chasti Tikhogo okeana vo vtoroy polovine XVIII v: sbornik dokumentov (Moscow: Nauka, 1989), 206. For background on these medals, see V. A. Durov, "Osvoyeniye Severo-Vostoka Rossii v russkikh nagradnykh medalyakh vtoroy poloviny XVIII v.” in N. K. Gavryushin and A. S. Fedorov, eds., Pamyatniki nauki i tekhniki 1985 (Moscow: Nauka, 1986), 119-24; and Andrei V. Grinev, "Russian Award Medals for the Natives of Alaska," trans. Richard L. Bland, European Review of Native American Studies 18, no. 2 (2004): 21-31. 
fashion during Russian conquests in Central Asia-in the case of early Russian exploration, it served the purpose of a claim of discovery, analogous to the kind made by Spain. Russians intended the medallions not as a sign that the czar would rule Native Alaskans-with all the obligations of care and protection that would imply-but rather for the recipients "to display in their dwellings ... in order to signify to those who may stop there that this land and its inhabitants [were] already in Russian possession." ${ }^{74}$

Initially, Russians in California likewise used award medals to claim land by discovery..$^{75}$ In advance of the 1811 mission to reconnoiter the area north of San Francisco Bay, Baranov instructed Kuskov to "hide the secret markers that I have entrusted to you in appropriate places: one plaque no. 000" and "one coat of arms, and 30 new silver medallions, as well as the old 20 tin medallions" for Native Americans. ${ }^{76}$ Calling the plaque, coat of arms, and medallions "secret markers" suggests that they were meant to show that Russians had gotten there first.

By contrast, the Métini protocol portrayed the bestowal of a medal on $\mathrm{Chu}$-gu-an as a marker of cession and military alliance, hearkening back to the original meaning of such ceremonies as acts of imperial subjection. The protocol described the medal as marking an exchange of land for military aid, with the expectation that $\mathrm{Chu}$-gu-an would come to Russian aid as well: "it imposed upon him the obligation of solidarity and assistance should the occasion require it." Just as important, the medal gave other Native American leaders a chance to show their consent to the alliance. After Chugu-an took the medal, all the gathered leaders "declared their willingness [to assist the Russians] and expressed their thanks for the reception.” The protocol ended with an affidavit from Russian officials testifying that they had truthfully observed the Native Americans' words and gestures, giving the tribal leaders' actions the status of sworn fact. ${ }^{77}$

74. $R C, 1: 317$.

75. See Grinev, "Russian Award Medals for the Natives of Alaska." For the broader history of medal distribution in the Russian empire, see N. I. Chepurnov, Rossiyskiye nagradnyye medali, three vols. (Cheboksary, Russia: Publishing House of Chuvashiya, 1993).

76. $R C, 1: 281$. The use of medals and gifts to secure indigenous loyalty in California was preceded by the planting of plaques, dating as early as 1579 when Sir Francis Drake was said to have buried the famous "plate of brass" at Drake's Bay in California, but continuing until Kuskov's forays (Okun, Russian-American Company, 118, 121).

77. $R C, 1: 322$. 


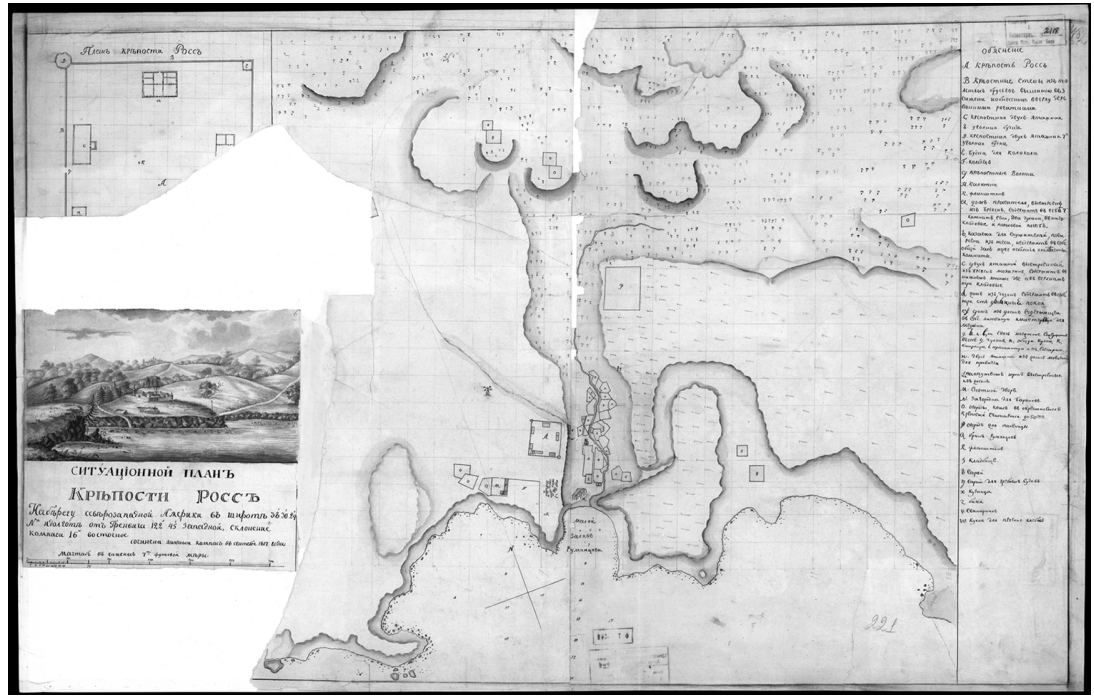

Figure 2. "Plan of Fortress Ross, 1817. Russian-American Company Map sent to Madrid, Courtesy of State Naval Archives, St. Petersburg, Russia." Courtesy of Fort Ross Digital Conservancy.

With its concluding presentation of a medal, the protocol offered a dramatic narrative of the company's rights under international law. In Chugu-an's cession of Métini and other tribal leaders' acclaim, all nearby challenges to Russian control-both from Chu-gu-an and from neighboring tribes-were seemingly preempted. More importantly from the company's point of view, the protocol proved the validity of their claim to rival European powers. Cession and military alliance made an argument for Russian ownership of the territory that was theoretically valid under international law. As much as the fort itself, Chu-gu-an's acceptance of the medal showed that the colony was lawfully occupied and defended, at least as the company saw things.

\section{THE AFTERLIFE OF THE MÉTINI PROTOCOL}

The Métini protocol was one among many legal documents company officials prepared to prove the legitimacy of Ross to imperial rivals, including a "Plan of Fort Ross" sent to Madrid (see figure 2). ${ }^{78}$ The protocol differed

78. The plan is currently located in the Russian State Archive of the Navy (Rossiyskiy gosudarstvenniy arkhiv Voenno-Morskogo Flota, or RGAVMF). 
from others, however, because it made a legal argument in dramatic form. The exchange of gifts and gratitude and the award medal distilled into one ceremony several legal arguments for possession, showing that Native Americans had ceded the land, that they had a reason for doing so, and that they would not attack the colony in the future. Yet as with other appeals to royal authority, company officials were uncertain about whether the document would have any effect. They had to await a response from the czar or his ministers as well as from Spanish diplomats to determine whether their creative dramatization of legal arguments had satisfied Russian imperial concerns or answered Spanish objections.

The immediate Russian response to the protocol was mixed. The document's first audience was Vasiliy Golovnin, a Russian Imperial Navy officer tasked with inspecting Ross during an 1817-19 circumnavigation of the world. After stopping at the colony, Golovnin took a copy of the protocol back to St. Petersburg. ${ }^{79}$ In 1822 he published a book about the voyage and described the document. His account revealed how colonial officials used the protocol to defend their right to occupy the land. Golovnin wrote that after he anchored his ship off the colony, "Mr Kuskov came aboard and brought with him various fresh provisions and a copy (solely for which I stopped here a second time) of a deed signifying that the land here had been ceded by the Indians to the Russians." 80 The fact that Golovnin mentioned sailing back to get the protocol shows the urgency the company faced in securing their claim to Ross, and the importance of their negotiations with Native Americans to that goal. Golovnin also offered his opinion of the protocol and its validity as a land claim. As a naval officer with involvement in colonial ventures, he had every incentive to embrace negotiations with Native Americans as a source of land rights. He therefore took a favorable view of the protocol, writing that the Russians "founded their settlement with the voluntary agreement of the native inhabitants of this country and with the permission of a people that does not recognize the authority of the Spaniards and that is permanently hostile to them." And, he continued, "This people gave [the Russians] the right to choose a site on the coast and to settle it for a certain payment, which was made in various goods. The continuing friendly disposition of this people to the Russians clearly attests that they did not take possession of this land by force." ${ }^{11}$ Though the protocol did not mention the sale of land for goods-instead portraying

79. $R C, 1: 390$.

80. $R C, 1: 352$.

81. $R C, 1: 355$. 
military alliance as the reason for the gift-Golovnin's interpretation reveals his conviction that company officials had lawfully acquired the land from its owner. Golovnin embraced Russian negotiations with the Kashaya Pomos and the Bodega Miwoks as evidence of the company's claims under international law. Their "continuing friendly disposition" was in his view sure proof of the company's rights.

A member of Golovnin's crew found it less credible, however, foreshadowing problems Ross officials would later face. Fëdor Litke, a midshipman aboard Golovnin's ship, commented on the protocol in his own narrative of the voyage and voiced skepticism about it. "[A]n agreement with a man who cannot read, write, or speak [Russian] and who in general does not have the slightest notion of the meaning of the agreement, can only serve as a pretence and not as a solid right and will probably be of no service," he wrote. ${ }^{82}$ Litke believed that Native Americans lacked the intellectual capacity to form valid contracts and assumed the imperial government would think the same. Though not representing any official opinion, Litke's reading of the protocol suggested that despite Golovnin's confident assertions, ministers in the imperial government might react with skepticism to land rights deriving from agreements with Native Americans. ${ }^{83}$

Litke was right that the imperial government would question the protocol, but he was wrong about the reasons. On November 3, 1818, the company's board in St. Petersburg made its official report on the protocol to the imperial ministry, based on a copy that had traveled by way of company headquarters in New Archangel, Alaska, in advance of the one carried home by Golovnin. Using the protocol as a basis, the report stated that the Native Americans living near the colony "all have unanimously expressed their pleasure that Russians settled among them." ${ }^{\text {84 }}$ However, instead of criticizing this claim based on Native Americans' supposed lack of understanding, as Litke had anticipated imperial ministers might, Minister of Internal

82. $R C, 1: 390$.

83. For the history of Russian ethnographers' understanding of language and ethnicity during this period, see Yuri Slezkine, "Naturalists Versus Nations: Eighteenth-Century Russian Scholars Confront Ethnic Diversity," Representations 47, special issue (Summer 1994): 186-90.

84. The report also noted that the Russians "became a barrier from attacks by remote Native Americans living in the surroundings of the Spanish fort of San Francisco," a description that is also false since it was the Spanish themselves and not Native Americans living near them who threatened the Bodega Miwoks and conceivably the Kashaya Pomos. "Glavnoye praveleniye Rossiysko-Amerikanskoy kompanii Alexandru I,” 10:576. 
Affairs Osip Kozodavlev criticized Hagemeister for exceeding his authority. "Because it is not stated in the report who authorized Captain-Lieutenant Gagemeister [Hagemeister] to give to the Indian chief ... a silver medallion with the inscription 'Allied to Russia' [sic], I therefore propose that the Board of Directors of the Russian-American Company should provide me with this information," he wrote..$^{85}$ Kozodavlev also asked the company to account for its distribution of medals to Native Americans, including "how many gold and silver medallions altogether . . . have been distributed, and to whom, and who still has them." ${ }^{86}$

Kozodavlev's objection to the protocol was less about Native American rights than about the company's overreaching its authority. Yet Kozodavlev's concern about how Russian medals circulated also showed his recognition that Native Americans had power and agency in such exchanges. ${ }^{87}$ The anthropologist Kent G. Lightfoot has argued that the Kashaya Pomos managed to exert some control over their dealings with the Russians by keeping the colonizers at a distance, working at the colony or visiting it for trade and retreating inland when they wished to avoid the newcomers. ${ }^{88}$ These retreats from colony to forest allowed goods acquired from Russians to pass inland to village clusters, as Kashaya Pomos incorporated Russian- and Asian-made goods into their own economic and political practices and redistributed them to villages beyond Métini. Like the goods the Russians had given to the Coast Miwoks and Kashaya Pomos in years prior, the unnamed "gifts" handed out by Russians at the 1817 meeting were probably destined for networks of exchange that stretched from coast to interior, and became part of Kashaya Pomo intervillage trading as well as their diplomacy with other tribes. Chu-gu-an's medal probably circulated in this fashion as well. When the board wrote back to Kozodavlev to report on the fate of the medals, they did not say what happened to it, other than to repeat that they had given it to Chu-gu-an. ${ }^{89}$ Their silence suggests they may have lost track of it, despite their order to Chu-gu-an to wear it. ${ }^{90}$ After acquiring medals from Russians, Native Americans apparently controlled their circulation.

The reaction from Spanish colonial officials presented an equally urgent

85. $R C, 1: 404$ (brackets added). The medal read "Allies of Russia" $(R C, 1: 322)$. The board answered saying it had given Hagemeister the authority to give the medal to $\mathrm{Chu}$-gu-an $(R C, 1: 405)$.

86. $R C, 1: 404$.

87. $R C, 1: 288$.

88. Lightfoot, Native Americans, Missionaries, and Merchants, 164-65.

89. $R C, 1: 405$.

90. $R C, 1: 322$. 
test of the protocol's success. Their direct response does not survive, but their answer to a similar account of Chu-gu-an's land cession that Kuskov delivered in person shortly before the protocol's creation shows their view of the company's arguments. In a journal of his service as a secretary on the same voyage that took Golovnin to Ross, Fëdor Matyushkin offered an account of a meeting between Kuskov and Golovnin, relating a story about a confrontation with Spanish officials regarding the company's claims to Métini. According to Matyushkin, Kuskov told Golovnin that in 1816, Otto von Kotzebue, a Russian naval officer, summoned him to San Francisco and "inquired of him in an imperious voice in the presence of Spanish officials by what right he had occupied this territory [Métini]." Matyushkin related that Kuskov "had to give an answer" but does not say what that answer was, reporting only that Kuskov "tearfully" lamented Kotzebue's questioning of him "in the presence of the Spaniards." ${ }^{91}$ Kotzebue's own narrative of a later visit to California in 1824, however, has a description of an undated confrontation between Kuskov and Spanish officials that he observed on an earlier voyage, in which Kuskov told the Spanish he had "settled in this region, which had not previously been in the possession of any other power, and over which, consequently, none had a right but the natives; that these latter had freely consented to his occupation of the land, and therefore that he would yield to no such unfounded pretension as that now advanced by the Spaniards." ${ }^{92}$ In this account of what is probably the same conversation reported by Kuskov to Golovnin, it is the Spanish, and not Kotzebue himself, who questioned Kuskov. It is possible that Kotzebue questioned Kuskov at Spanish behest and then elided this detail of the story in his own telling. But more importantly, Kotzebue's account shows that Kuskov used the same arguments found in the protocol to assert the company's rights to Métini, saying that Native Americans "had freely consented to [Kuskov's] occupation of the land." The fact that Kotzebue approvingly repeated this argument in his own narrative suggests that he supported the company's claims, Kuskov's "tearfu[1]" lamentations about the interrogation in front of Spanish officials notwithstanding. But the Spanish complaints voiced to Kotzebue also suggest that Spanish colonial officials rejected rights deriving from Native American owners. Indeed, Kuskov's worries about how Kotzebue would report this whole exchange may have been the immediate impetus for drafting the protocol in the first place.

The United States, which had claims to the Columbia River, presented

91. $R C, 1: 399$ (brackets added).

92. Von Kotzebue, A Nerw Voyage Round the World, 2:122. 
another threat to Ross. Russian-American Company officials had initially feared that the United States might move to destroy Ross, mentioning a possible American threat in their pleas to the imperial government for protection in $1809 .{ }^{93}$ But unlike Spain, the United States did not make plans to eliminate Ross; a congressional committee reported in 1821 that the Russian-American Company was only trading in the region. ${ }^{94}$ Either Russian imperial ministers had not given the protocol to the United States, or the Americans ignored it. Either way, Golovnin wrote a response to the congressional report heatedly asserting that its authors had overlooked Russian exploration of the coast. ${ }^{95} \mathrm{His}$ omission of any reference to Native American exchanges was significant. Despite embracing land cession elsewhere, in his response to the United States, Golovnin asserted rights based on discovery, arguing that the Russians had the right to occupy California because they had extensively explored the region. ${ }^{96}$ Golovnin apparently did not think Chu-gu-an's cession would be recognized by the United States.

Russian colonists, so confident in their assertions in the protocol, found themselves unable to persuade Spanish officials, U.S. congressional representatives, or even imperial ministers in their own government of claims deriving from Native American sources. Russia's imperial rivals either rejected or ignored company officials' negotiations with tribal leaders, refusing to recognize them as a land transaction. But these were not the only groups with a stake in the proceedings. The Kashaya Pomos and the Bodega Miwoks also had stories to tell. And though company officials had misrepresented their relationship with the tribes in the protocol, the Russians' focus on the importance of Native Americans' consent gave tribal leaders leverage in their trade and diplomacy with the Russians.

\section{BODEGA MIWOK AND KASHAYA POMO ACCOUNTS OF THE 1817 MEETING}

As copies of the Métini protocol made their way back to Russia, accounts of the 1817 meeting at Ross also passed through Native American channels.

93. $R C, 1: 276$.

94. See John Floyd, "Occupation of the Columbia River," The Quarterly of the Oregon Historical Society 8, no. 1 (1907): 69.

95. See V. M. Golovnin, Around the World on the Kamchatka, 1817-1819, trans. Ella Lury Wiswell (Honolulu: Hawaii Historical Society, 1979), appendix VII, 311-22, 317.

96. Golovnin, Around the World on the Kamchatka, 321n17. In claiming there was "no trade," Golovnin meant large-scale export of commodities. The remark shows that he did not consider the company's participation in Kashaya Pomo exchange networks to be trade. 
Reports about Native American interpretations of the meeting suggest that tribal leaders, far from feeling cheated, saw it as an opportunity to increase their trade with Europeans and bolster their standing among other Native Americans. During the same voyage on which he collected the protocol, Golovnin met with a Bodega Miwok chief living in Bodega Bay whom he called "Valenila," who was probably the same leader as the "Gem-le-le" in the protocol. ${ }^{97}$ In the meeting Valenila "asked [Golovnin] for a Russian flag so that with the appearance of Russian ships he would be able to raise it as a sign of friendship of the people ruled by him with the Russians," a request Golovnin granted. ${ }^{98}$ The request suggests how Valenila might have viewed the meeting at Métini: Valenila clearly thought that imperial gifts, such as the medal bestowed on $\mathrm{Chu}$-gu-an, conveyed great benefits to tribal leaders. He wanted a flag for himself so that he could enjoy the same advantages. $\mathrm{He}$ also wanted the flag as a way to establish trade relations with passing ships not under their control. ${ }^{99} \mathrm{He}$ knew that other Russians were independent of Ross and hoped that, with the flag, he could deal with them directly. Thus, he wanted the flag not as a sign of submission to Russian colonists, but as an entrée to expanded opportunities for trade. Perhaps Chu-gu-an used the medal in that way as well. In any case, the possibility of such unauthorized use of imperial symbols may have been one reason Kozodavlev questioned Ross officials about the medals.

There was also a Bodega Miwok story about Métini that differed from the protocol. In his account of a meeting with Bodega Miwok converts in 1822, the Franciscan friar Mariano Payeras described how the converts viewed the Kashaya Pomos' agreements with the Russian-American Company. Pointedly, the converts told Payeras that the Russians bought only Ross but "not the neighboring places." The converts further limited Russian

97. A digest of the protocol the company's board of directors sent to Alexander I referred to Gem-le-le as Bale-lii-lye, probably a variant of Valenila ("Glavnoye pravleniye Rossiysko-Amerikanskoy kompanii Aleksandru I," 10:576). At the time of the meeting in the protocol, the Bodega Miwoks were led by Gem-le-le's father Yolo, who died only in 1818 (Payeras, Writings of Mariano Payeras, 335). Gem-le-le probably represented the Bodega Miwoks at the negotiations because Yolo was ailing $(R C, 1: 399-400)$. Yolo's death was depicted by the Russian painter Mikhail Tikhanov, who witnessed it $(R C, 1: 397)$.

98. $R C, 1: 370$. An alternate account of what was probably the same meeting appears in $R C, 1: 399-400$.

99. Fëdor Matyushkin stated that Valenila "was ordered to raise [the flag] as soon as he sighted a ship with the same . . promising him in that case rich gifts from our compatriots" ( $R C, 1: 399)$. 
rights to Bodega Bay, stating that Russians had "not purchased" any territory in the bay but only secured "permission" to stay there. ${ }^{100}$ Recounting the treaty to Payeras, the Bodega Miwok converts sharply limited Russian claims in their area, describing them as rights of temporary occupancy. Moreover, they did not mention political subjection of any kind to the Russians, suggesting that the medal had not signified any allegiance to the czar. The converts' testimony suggests that, at least from the Bodega Miwoks' point of view, the Russians' gains were far less than the protocol reported.

Of course, as an agent of an imperial rival to Russia who was elsewhere involved in negotiations about land rights, Payeras had an interest in promoting a skeptical view of Russian rights in the region. ${ }^{101}$ The same is true of the Bodega Miwok converts, who sought Russian protection but downplayed Russian rights. They were one of many parties who framed the story of Métini in their own terms and in accord with their own agendas. Regardless of either party's motives, Payeras's exchange with the converts underscores that the protocol was not a local affair but a geopolitical event. Company officials, imperial ministers, diplomats of Russia's imperial rivals, and Native Americans on the coast all viewed the 1817 meeting differently, depending on their framework for understanding land rights.

European debates about the protocol lasted only a few years. When revolution came to Spain in 1820, the Russian government and Spanish diplomats largely abandoned their dispute over the status of Ross. In 1821 Mexico achieved independence from Spain, once and for all removing Ross from Spanish claims. Like Spain, Mexico persistently challenged Russian rights in the region. Ross officials did not mention Native American treaties in defense, however, emphasizing instead the Treaty of Velikiye Luki and an 1812 treaty between Alta California and the Russian-American Company. ${ }^{102}$ From then on Russians in California did not invoke Métini as a formerly Kashaya Pomo territory, and Native American rights were no longer part of their claims. Assertions about agreements with Kashaya Pomos and Bodega Miwoks appear to have been intended primarily to persuade Russian authorities or Spanish diplomats. These metropolitan officials were schooled in European ideas of international law such as discovery,

100. Payeras, Writings of Mariano Payeras, 335. Timofey Tarakanov was not the commander of a Russian ship but rather the leader of a hunting party. For an explanation of the Bodega Miwoks' mistaken belief that Tarakanov had purchased Fort Ross, see Farris, "Talcani."

101. $R C, 1: 490-91$.

102. $R C, 1: 490-92$. For background, see William Richardson, Mexico Through Russian Eyes, 1806-1940 (Pittsburgh, Pa.: University of Pittsburgh Press, 1988). 
cession, and alliance, whereas Ross officials did not seem to think that Mexican officials would assign any significance to Native American rights. In Russian-American Company discussions with Mexico, the Métini protocol ceased to have any relevance to disputes over land rights.

The historians James R. Gibson and Alexei A. Istomin have argued that after 1825, the Russian government "simply put the question of Ross aside," leading to a period of prolonged uncertainty over the status of the colony in Russian imperial plans until its sale in 1841 to rancher John Sutter. ${ }^{103}$ Although the Métini protocol was written for a European audience, the principles of alliance it articulated were still apparently meaningful to the Bodega Miwoks and Kashaya Pomos for decades after. An 1833 account of Bodega Bay by a Mexican military officer described a leader named Gualinela-possibly the Gem-le-le mentioned in the protocol-guarding Russian buildings in exchange for protection of his rancheria. ${ }^{104}$ The military alliance between the colony and surrounding Native Americans thus continued to have some meaning years later, despite the Russians' refusal to protect the tribes when Kuskov had sent them to fight the Spanish in 1817. For their part, the Kashaya Pomos never called on the Russians for help. As late as the 1950s, however, Kashaya Pomo storytellers still remembered instances of equitable treatment by the Ross colonists that were consistent with the principles of reciprocity found in the protocol. ${ }^{105}$

The Métini protocol has a divided legacy. It recorded Kashaya Pomo and Bodega Miwok responses to colonial invasion but did so for decidedly colonial reasons. Nevertheless, the protocol reveals how, in the workings of imperialism in the Pacific world, diplomacy with Native Americans had geopolitical significance, even as indigenous territories came under imperial control.

103. "Introduction," in $R C, 1: 154$.

104. Glenn J. Farris, "Story of the Purchase of Fort Ross and Payment for Bodega Bay by the Russian Promyshlennik, Tarakanov," Fort Ross Conservancy Digital Library, Jenner, Calif., April 14, 1994, 6.

105. See Lightfoot, Native Americans, Missionaries, and Merchants, 164-65. For reciprocity, see James, "The Last Vendetta"; and Herman James, "The WifeBeater," as told to Oswalt, September 1958, Kashaya Texts, 269-71. 